\title{
PREVALENCE OF JOINT PAIN AND OSTEOARTHRITIS IN OBESE BRAZILIAN POPULATION
}

\author{
Prevalência de dor articular e osteoartrite na população obesa brasileira
}

Daniel Moreira PACCA1', Gustavo Constantino DE-CAMPOS ${ }^{1}$, Alessandro Rozin ZORZI'1, Elinton Adami CHAIM ${ }^{2}$, Jõao Batista DE-MIRANDA ${ }^{1}$

How to cite this article: Pacca DM, De-Campos GC, Zorzi AR, Chaim EA, De-Miranda JB. Prevalence of joint pain and osteoarthritis in obese Brazilian population. ABCD Arq Bras Cir Dig. 2018;31(1):e1344. DOI: /10.1590/0102-672020180001e1344

From the ${ }^{1}$ Departamento de Ortopedia e Traumatologia and ${ }^{2}$ Departamento de Cirurgia, Universidade Estadual de Campinas ('Orthopedics Department and 2Surgery Department, State University of Campinas), Campinas, SP, Brazil

HEADINGS - Osteoarthritis. Obesity. Bariatric surgery.

\section{Correspondence:}

Gustavo Constantino de-Campos

E-mail: gustavoccampos@usp.br; gustavoccampos@terra.com.br

Financial source: none

Conflict of interest none

Received for publication: 28/11/2017 Accepted for publication: 06/02/2018

DESCRITORES - Osteoartrite. Obesidade. Cirurgia bariátrica.
ABSTRACT - Background: High body mass index, as well as maintaining this condition for a long period of time, are important risk factors for the development of osteoarthritis. Aim: To determine joint pain and osteoarthritis prevalence in patients referred to bariatric surgery. Methods: Morbidly obese patients referred to bariatric surgery responded to the visual analogue pain scale (VAS) and the WOMAC questionnaire. X-rays of the hips and knees were evaluated. The primary endpoints were self-reported joint pain and the diagnosis of osteoarthritis by clinical and radiological criteria of the American College of Rheumatology. Results: 141 patients were interviewed ( $85.1 \%$ women) with a mean age of 40 years. The mean body mass index was 46 . The lumbar spine and knee joint were the most commonly reported as painful (77.9\% and $73.2 \%$ respectively). Prevalence of knee osteoarthritis was $63.1 \%$ and hip osteoarthritis was $40.8 \%$. Age, mean VAS and WOMAC scores were higher in the osteoarthritic individuals. Conclusion: There is prevalence of $90.1 \%$ of pain symptoms in morbidly obese patients referred to bariatric surgery. The prevalence of knee osteoarthritis was $63.1 \%$ and hip osteoarthritis was $40.8 \%$ in this sample.
RESUMO - Racional: Alto índice de massa corpórea, assim como a manutenção desta condição por longo período de tempo, são importantes fatores de risco para o desenvolvimento de osteoartrite. Objetivo: Determinar a prevalência de dor articular e osteoartrite em pacientes aguardando cirurgia bariátrica. Métodos: Pacientes obesos mórbidos responderam à escala e questionário (VAS e WOMAC) de dor e função. Radiografias dos quadris e joelhos foram avaliadas. Os desfechos primários foram dor articular referida nos questionários e o diagnóstico de osteoartrite feito através dos critérios clinicoradiológicos do Colégio Americano de Reumatologia. Resultados: Cento e quarenta e um pacientes foram entrevistados $(85,1 \%$ mulheres) com idade média de 40 anos. A média do índice de massa corpórea foi de 46. Coluna lombar e joelhos foram as regiões mais comumente referidas com dor $(77,9 \%$ e $73,2 \%$ respectivamente). A prevalência de osteoartrite dos joelhos foi de $63,1 \%$ e dos quadris foi de $40,8 \%$. Idade, média da escala visual de dor e resultados do questionário de WOMAC foram maiores nos indivíduos com osteoartrite. Conclusão: Há prevalência de 90,1\% de sintomas dolorosos nos pacientes obesos mórbidos encaminhados para cirurgia bariátrica. A osteoartrite dos joelhos foi de $63,1 \%$ e de quadris de $40,8 \%$.
O steoarthritis (OA), the most common form of joint disease ${ }^{10}$; it is a multifactorial pathology that leads to articular cartilage damage ${ }^{11}$ and inflammatory changes in the joint $t^{4,21}$. OA is a slow and gradual process, highly prevalent in the adult population, which causes pain, loss of function and poor quality of life, especially in the elderly and obese individuals ${ }^{5}$. High body mass index (BMI), as well as maintaining this condition for a long period of time, are important risk factors for its development ${ }^{14}$.

The World Health Organization (WHO) estimates that $10 \%$ of the population over 60 years has serious medical problems resulting from $\mathrm{OA}^{20}$. Lawrence et al. ${ }^{10}$ estimate a prevalence of 27 million people with it in the adult population of the United States. Senna et al. ${ }^{16}$ reported in 2004 a prevalence of $4.14 \%$ in the Brazilian population. A large increase in numbers is expected in Brazil, since Brazilian population is aging and becoming increasingly obese $\mathrm{e}^{5}$. There is a direct relationship between the prevalence of $\mathrm{OA}$ and increasing age and $\mathrm{BMI}^{19}$.

Obesity is also a condition that imposes heavy burden on society. Obese individuals have increased cardiovascular events and many other conditions, including osteoarthritis, which is strongly associated with high metabolic and inflammatory environments ${ }^{17}$. Besides the obvious mechanical overload, cytokines associated with adipose tissue, including adiponectin, leptin and resistin also influence the onset and 
worsening of OA through direct degradation of the joint or inflammatory processes stimulation ${ }^{17}$. Literature shows clear relationship between weight loss through bariatric surgery and OA symptoms improvement ${ }^{1,7,8}$.

Prevalence of osteoarthritis in Brazilian adult population is $4.14 \%$ according to the only existing study on the subject ${ }^{16}$. Obesity is a major risk factor for osteoarthritis. An American study revealed a prevalence of $22.9 \%$ of osteoarthritis in obesity surgery patients ${ }^{15}$. There are no national studies assessing the prevalence of joint pain and osteoarthritis in the Brazilian obese population.

The aim of this study was to define the prevalence of joint pain and osteoarthritis of the knees and hips of obese patients awaiting treatment of obesity through bariatric surgery.

\section{METHODS}

This is a prevalence study (cross-sectional) conducted in a bariatric surgery service between July and December 2015 and was approved by the local Research Ethics Committee.

\section{Patients}

Were evaluated 141 consecutive patients in preoperative assessment for bariatric surgery. Inclusion criteria were obese with $\mathrm{BMI}$ above 35 referred for bariatric surgery and ability to read, understand and accept the informed consent.

\section{Clinical evaluation}

Patients responded to visual analogue pain scale $(\text { VAS })^{3}$ and Western Ontario and McMaster Universities (WOMAC) questionnaire ${ }^{6}$. The presence of articular pain was investigated. Anthropometric data also were collected, such as age, gender, race, height and weight, and BMI was calculated dividing weight $(\mathrm{kg})$ by squared height (meters).

\section{Radiological assessment}

Patients underwent radiographs of the hips (anteroposterior incidence) and knees (unilateral weight bearing, patellar axial and lateral views). The radiographs were classified according to Kellgren and Lawrence classification ${ }^{16}$.

The primary outcomes were presence of self-reported joint pain and diagnosis of osteoarthritis according to the clinical and radiological American College of Rheumatology criteria for knee and hip $\mathrm{OA}^{2}$.

\section{Statistical analysis}

Descriptive analysis was performed for all variables. Data was presented as mean and standard deviation (SD) for continuous variables and as absolute frequency and relative frequency for categorical variables. Kolmogorov-Smirnov test, histograms and multivariate skewness and kurtosis measures were applied to determine which variables were normally distributed. Comparisons between two continuous variables were performed using the Student-t test for independent samples and with Mann-Whitney u test when data did not meet conditions for use of parametric tests. Binary logistic regression was performed to test the association between total prevalence of OA, prevalence of knee OA and hip OA (dependent variables) and the risk factors such as age, gender, height, weight and BMI. Results were described as Odds Ratio (OR) (95\% confidence intervals, p-value). Chi-square test was used for categorical variables, or Fisher's exact test when $20 \%$ or more of the table cells showed absolute count of less than five. The level of significance was set at 0.05 . All reported $p$ values are two-tailed. All analyzes were performed using IBM SPSS Statistics software (version 22.0 Armonk, NY, IBM Corp.).

\section{RESULTS}

\section{Descriptive statistics}

One hundred forty-one patients were analyzed. Demographic characteristics of the sample are shown in Table 1.

TABLE 1 - Patients demographics

\begin{tabular}{|l|c|} 
& $\begin{array}{c}\text { Mean } \pm \text { SD or } \\
\text { Absolute frequency (relative) }\end{array}$ \\
\hline Age & $39.7 \pm 11.5$ \\
\hline Height & $1.63 \pm 0.09$ \\
\hline Weight & $123.8 \pm 28.5$ \\
\hline BMI & $46.6 \pm 8.9$ \\
\hline Gender & \\
\hline Male & $21(14.9 \%)$ \\
\hline Female & $120(85.1 \%)$ \\
\hline
\end{tabular}

$\mathrm{SD}=$ standard deviation; $\mathrm{BMI}=$ body mass index

Prevalence of musculoskeletal pain in this sample of morbidly obese patients was very high. Only 14 patients (9.9\%) had no complaints. The other $127(90.1 \%)$ reported pain in one or more joints. The most common pain site was the lumbar spine, followed by the knees. Of these 127 patients with pain, 99 (77.9\%) had low back pain, 33 (25.9\%) dorsal pain, 33 (25.9\%) cervical pain, 93 (73.2\%) knee pain, 61 (48.1\%) hip pain and 54 $(42.5 \%)$ reported pain in the hands. Only 15 patients (11.8\%) reported pain on a single joint. Moment VAS had a mean of 39.9 \pm 34.6. Last three days's VAS was $52.4 \pm 34.1$.

Mean total WOMAC was $36.3 \pm 21$.2. Mean WOMAC pain subscale was 7.9 \pm 4.6 . Mean WOMAC stiffness subscale was 2.8 \pm 2.4. Mean WOMAC function subscale was $25.6 \pm 15.5$. The result of the total WOMAC questionnaire and its subscales (pain, stiffness and function) are shown in Figure 1.
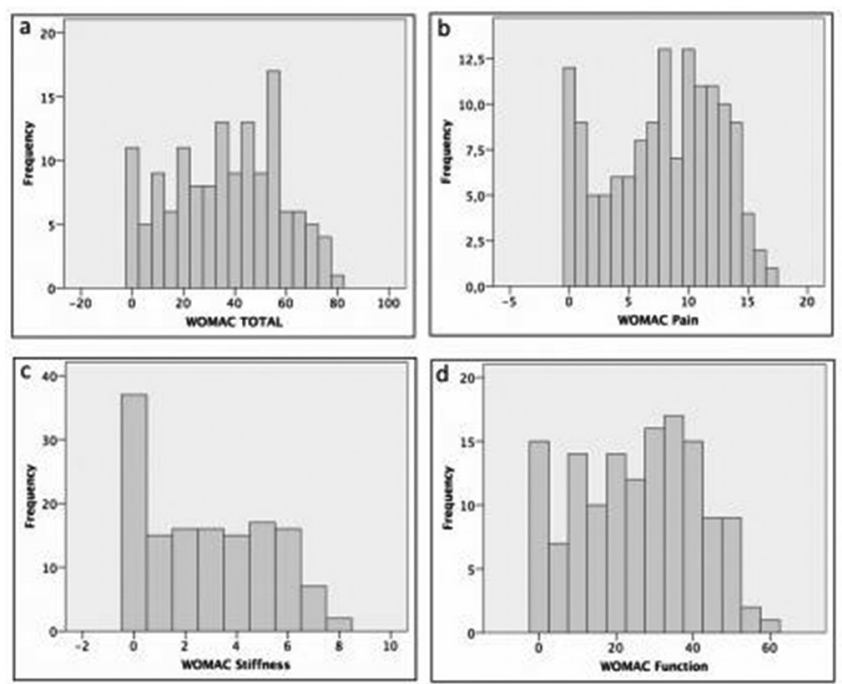

FIGURE 1 - Histograms: A) WOMAC total; B) WOMAC pain subscale; C) WOMAC stiffness subscale; D) WOMAC function subscale data distribution

Radiographs were taken in 103 patients. The other 38 patients refused or did not attend to the scheduled examination. Radiographs were classified according to the Kellgren-Lawrence scheme $(K \& L)$ by three authors. In case of disagreement, the classification given by the majority (two observers) was considered. There was no total disagreement.

In these 103 patients, 80 (77.7\%) had one or more joints with joint pain and radiological changes consistent with $\mathrm{OA}$ $(K \& L \geq 2)$. The prevalence of knee OA was $63.1 \%(n=65)$ and hip OA was $40.8 \%(n=42)$. 


\section{Analytical statistics}

There was no difference between the prevalence of OA and gender considering any joint (male $=10,58.8 \%$; female $=70$ $81.4 \% ; p=0.056)$, only knee $O A(M=9, F=56 ; p=0.412)$ or only hip $\mathrm{OA}(\mathrm{M}=4, \mathrm{~F}=38, \mathrm{p}=0.176)$. Regarding the continuous variables, comparisons between the average of the group with OA (K\&L $\geq 2)$ and without $O A(K \& L \leq 1)$ are shown in Table 2 .

TABLE 2- Comparison of continuous variables between obese individuals with or without OA

\begin{tabular}{|c|c|c|c|}
\hline & $\begin{array}{c}\text { With OA } \\
(n=80)\end{array}$ & $\begin{array}{l}\text { Without OA } \\
\quad(n=23)\end{array}$ & $\mathbf{p}$ \\
\hline Age & $41.3 \pm 12.1$ & $35.3 \pm 8.9$ & 0.020 * \\
\hline Weight & $121.5 \pm 26.6$ & $134.4 \pm 38.2$ & 0.193 \\
\hline Height & $1.61 \pm 0.20$ & $1.66 \pm 0.11$ & 0.262 \\
\hline BMI & $45.1 \pm 9.3$ & $48.1 \pm 10.7$ & 0.424 \\
\hline WOMAC total & $41.1 \pm 19.8$ & $29.3 \pm 22.9$ & $0.017^{*}$ \\
\hline WOMAC pain & $9.0 \pm 4.3$ & $5.7 \pm 4.9$ & $0.004^{*}$ \\
\hline WOMAC stiffness & $3.2 \pm 2.3$ & $2.0 \pm 2.2$ & $0.026 *$ \\
\hline WOMAC function & $28.9 \pm 14.4$ & $21.7 \pm 16.4$ & $0.046^{*}$ \\
\hline VAS moment & $44.9 \pm 33.6$ & $33.7 \pm 33.4$ & 0.174 \\
\hline VAS 3-days & $61.2 \pm 30.8$ & $38.4 \pm 34.8$ & $0.011 *$ \\
\hline
\end{tabular}

${ }^{*} \mathrm{p}<0.05$. OA=osteoarthritis; $\mathrm{BMI}=$ body mass index; $\mathrm{VAS}=\mathrm{visual}$ analogue scale WOMAC $=$ Western Ontario and Mcmaster Universities questionnaire

The age of the patients with OA was higher, as well as the WOMAC and last three days VAS levels. Associations between continuous variables as potential risk factors for developing OA tested by binary logistic regression are presented in Tables 3 and 4.

TABLE 3 - Binary logistic regression for knee or hip OA risk factors

\begin{tabular}{|c|c|}
\hline & $\begin{array}{c}\text { OA total } \\
\text { OR }(\mathrm{CI}) ; p \text { value }\end{array}$ \\
\hline Age & $1.054(1.003-1.107) ; p=0.037^{*}$ \\
\hline Weight & $1.009(0.944-1.079) ; p=0.783$ \\
\hline Height & $0.187(0.000-2.628) ; p=0.731$ \\
\hline $\mathrm{BMI}$ & $0.972(0.805-1.173) ; p=0.766$ \\
\hline Gender & $0.302(0.056-1.631) ; p=0.166$ \\
\hline
\end{tabular}

TABLE 4 - Binary logistic regression for knee and hip OA risk factors

\begin{tabular}{ccc} 
& $\begin{array}{c}\text { Knee OA } \\
\text { OR }(\mathrm{Cl}) ; \mathrm{p} \text { value }\end{array}$ & $\begin{array}{c}\text { Hip OA } \\
\text { OR }(\mathrm{Cl}) ; \mathrm{p} \text { value }\end{array}$ \\
\hline Age & $1.032(0.992-1.073) ; \mathrm{p}=0.119$ & $1.023(0.986-1.061) ; \mathrm{p}=0.230$ \\
\hline Weight & $1.047(0.887-1.236) ; \mathrm{p}=0.588$ & $0.996(0.960-1.032) ; \mathrm{p}=0.815$ \\
\hline Height & $0.000(0.000-6.589) ; \mathrm{p}=0.556$ & $0.091(0.001-5.480) ; \mathrm{p}=0.251$ \\
\hline BMI & $0.851(0.536-1.349) ; \mathrm{p}=0.491$ & $1.016(0.916-1.127) ; \mathrm{p}=0.764$ \\
\hline $\begin{array}{c}\text { Gender } \\
\text { 0.696(0.153-3.172); } \mathrm{p}=0.640\end{array}$ & $0.602(0.130-2.780) ; \mathrm{p}=0.516$ \\
\hline $\begin{array}{c}\text { * } \mathrm{p}<0.05 . \mathrm{OA}=\text { osteoarthritis; OR=Odds Ratio; } \mathrm{Cl}=\text { confidence interval; } \mathrm{BMI}=\text { body } \\
\text { mass index }\end{array}$
\end{tabular}

\section{DISCUSSION}

This study found a high prevalence of joint pain, especially in the lumbar spine and knees, as well as OA in the hips and knees in a population of morbidly obese patients awaiting for bariatric surgery. This is the first Brazilian report of prevalence of pain and OA in morbidly obese population.

Aging and obesity are the two main risk factors for OA development ${ }^{5}$. There is a strong tendency, therefore, of a great increase in its prevalence in our country, since according to governmental reports the Brazilian population is getting older and heavier 5,14 . The number of individuals over 60 years old increased from 7.2 million in 1980 to 19.2 million in 2010, and probably will reach 64 million in $2050^{5}$. Recent decades has also witnessed significant increase in population's overweight (BMI between 25-30) and obesity (BMI above 30 ) rates and for the first time the number of overweight or obese people exceeded $50 \%$ of the Brazilian population ${ }^{14}$.

It is currently known that knee OA is strongly associated with high metabolic and inflammatory environments found in obesity ${ }^{9}$. Cytokines associated with adipose tissue, including adiponectin, resistin and leptin may influence OA through direct articular degradation of by enhancing local inflammatory processes. Although not all obese people will develop knee OA, it appears to be strongly associated with the coexistence of disorders of lipid and glucose metabolism. Furthermore, the higher load present on obese joints can be detected by mechanoreceptors on the surface of chondrocytes, triggering intracellular signaling cascades of cytokines, growth factors and matrix metalloproteinases ${ }^{12}$.

This study, as reported in the literature, found a direct relationship between age, obesity and osteoarthritis. The present analysis did not find significant statistical correlation between gender and $O A$, maybe be due to the low number of males in our sample. The vast majority of our subjects were female. There is increasing evidence that estrogen plays an important role in maintaining homeostasis of articular tissues. The dramatic increase in the prevalence of OA in women after menopause ${ }^{18}$, which is associated with the presence of estrogen receptors in articular tissues, suggests a link between OA and loss of ovarian function ${ }^{18}$. Although great attention is focused on estrogen's effect on articular cartilage, its deficiency also affects other joint tissues involved in OA, like subchondral bone, synovium, muscle, ligament and capsule ${ }^{13}$.

Since $\mathrm{OA}$ is a chronic disease, prevalence measurement becomes much more important than incidence and can indicate the risk of exposure for susceptible individuals. Prevalence studies are often used for planning public health and as an initial step (baseline) to assess comorbidity control programs.

In addition to the simple prevalence of the disease, we also obtained the algofunctional profile of the studied individuals through the application of Analogue Visual Scale of pain (VAS) and WOMAC questionnaire. We could also observe greater pain and loss of function in the OA individuals, which had almost twice the pain and loss of function expressed by a higher score on the WOMAC questionnaire. It is important to notice that even individuals without OA diagnosis presented with high WOMAC scores, which points out the functional limitation imposed by the presence of obesity. Several studies have shown an improvement of symptoms and quality of life in obese osteoarthritic subjects treated with bariatric surgery ${ }^{1,7,8}$.

The main limitation of this study is that the sample is composed of individuals referred for surgical treatment of obesity in the public system. There could be some degree of selection bias since joint pain can act as a motivator to make the individual seek surgical treatment. Thus, the prevalence of joint pain and OA could be expected to be smaller in the general Brazilian obese population. To overcome such limitation it would be necessary to carry out a sampling study in the Brazilian population involving home visits, much more expensive and time consuming.

Our next step will be to re-evaluate the individuals after bariatric surgery and observe any correlation between this treatment and changes in symptoms caused by osteoarthritis. 


\section{CONCLUSION}

There is a prevalence of $90.1 \%$ of pain symptoms in morbidly obese patients awaiting treatment with bariatric surgery. The prevalence of knee OA was $63.1 \%$ and hip OA was $40.8 \%$ in this sample.

\section{REFERENCES}

1. Abu-Abeid S, Wishnitzer N, Szold A, Liebergall M, Manor O. The influence of surgically-induced weight loss on the knee joint. Obes Surg. 2005;15(10): 1437-42.

2. Altman R,AschE, BlochDetal.Developmentofcriteriafortheclassification and reporting of osteoarthritis. Classification of osteoarthritis of the knee. Diagnostic and Therapeutic Criteria Committee of the American Rheumatism Association. Arthritis Rheum. 1986; 29(8):1039-49.

3. Carlsson AM. Assessment of chronic pain. I. Aspects of the reliability and validity of the visual analogue scale. Pain. 1983;16(1):87-101.

4. de Lange-Brokaar BJ, Ioan-Facsinay A, van Osch GJ et al. Synovial inflammation, immune cells and their cytokines in osteoarthritis: a review. Osteoarthritis Cartilage. 2012;20(12):1484-99.

5. deRezendeMU,deCamposGC,PailoAF.Currentconceptsinosteoarthritis. Acta Ortop Bras. 2013;21(2):120-2

6. Fernandes MI. Tradução e validação do questionário de qualidade de vida específico para osteoartrose WOMAC (Western Ontario McMaster Universities) para a língua portuguesa. São Paulo: Universidade Federal de São Paulo; 2003.

7. Gill RS, Al-Adra DP, Shi X et al. The benefits of bariatric surgery in obese patients with hip and knee osteoarthritis: a systematic review. Obes Rev. 2011; 12(12):1083-9.

8. Groen VA, van de Graaf VA, Scholtes VA et al. Effects of bariatric surgery for knee complaints in (morbidly) obese adult patients: a systematic review. Obes Rev. 2015;16(2): 161-70.
9. Kellgren JH, Lawrence JS. Radiological assessment of osteo-arthrosis. Ann Rheum Dis. 1957; 16(4):494-502.

10. Lawrence RC, Felson DT, Helmick CG et al. National Arthritis Data Workgroup. Estimates of the prevalence of arthritis and other rheumatic conditions in the United States. Part II. Arthritis Rheum. 2008;58(1):26-35.

11. Martel-Pelletier J, Boileau C, Pelletier JP, Roughley PJ. Cartilage in normal and osteoarthritis conditions. Best Pract Res Clin Rheumatol. 2008;22(2):351-84.

12. Mündermann A, Dyrby CO, Andriacchi TP. Secondary gait changes in patientswithmedial compartmentkneeosteoarthritis:increased loadatthe ankle, knee, and hip during walking. Arthritis Rheum. 2005;52(9):2835-44

13. Roman-BlasJA, CastañedaS, LargoR, Herrero-BeaumontG.Osteoarthritis associated with estrogen deficiency. Arthritis Res Ther. 2009;11(5):241.

14. Rosales Ade L, Brito NL, Frucchi R et al. Obesity, ostearthritis and clinical treatment. Acta Ortop Bras. 2014;22(3):136-9.

15. Scott SK, Rabito FA, Price PD et al. Comorbidity among the morbidly obese: a comparative study of 2002 U.S. hospital patient discharges. Surg Obes Relat Dis. 2006;2(2):105-11.

16. Senna ER, De Barros AL, Silva EO et al. Prevalence of rheumatic diseases in Brazil:astudyusingtheCOPCORDapproach.JRheumatol.2004;31(3):594-7.

17. Sowers MR, Karvonen-Gutierrez CA. The evolving role of obesity in knee 18. osteoarthritis. Curr Opin Rheumatol. 2010; 22(5):533-7.

19. Srikanth VK, Fryer JL, Zhai G, et al. A meta-analysis of sex differences prevalence, incidence and severity of osteoarthritis. Osteoarthritis Cartilage. 2005;13(9):769-81.

20. Stevens M, Paans N, Wagenmakers R et al. The influence of overweight/ obesityon patient-perceived physicalfunctioningandhealth-relatedquality of life after primary total hip arthroplasty. Obes Surg. 2012;22(4):523-9.

21. Woolf AD, Pfleger B. Burden of major musculoskeletal conditions. Bull World Health Organ. 2003;81(9):646-56.

22. Zini C, Stieven-Filho E, Tabushi FI, Ribas CA, Ribas FM, Opolski AC, Erbano BO. Knee arthroscopic visibility alterations in obese and non-obese patients. Arq Bras Cir Dig. 2016; 29 (Suppl 1):75-79. 